\title{
Weed community composition in different agro-systems
}

\author{
Isabella Sichierski Cardoso', Adriano Jakelaitis'*, Michellia Pereira Soares², \\ Vinícius Tavares de Araújo', Paulo Henrique Ramos Cabral' \\ IInstituto Federal de Educação, Ciência e Tecnologia Goiano, Rio Verde, GO, Brasil \\ ${ }^{2}$ Instituto Federal de Educação, Ciência e Tecnologia do Norte de Minas, Salinas, MG, Brasil \\ *Autor correspondente, e-mail: ajakelaitis@yahoo.com.br
}

\begin{abstract}
Weed communities in agricultural systems are diverse and subjected to different agronomic practices. In this study, a phytosociological survey of the weed community in different cropping systems consisting of corn, horticulture, perennial cultivation of Jatropha curcas and pasture of Urochloa brizantha in Rio Verde, GO, Brazil, was carried out. Assessments were performed at the beginning (October 2011) and at the end (March 2012) of the rainy season. After identifying and counting species, were calculated the phytosociological indices of density, frequency, abundance and relative importance, as well as the diversity index of Shannon-Wiener, evenness index of Pielou and similarity coefficient of Sorense. Were found 46 species of sixteen families, especially Poaceae. The most important species were: Alternanthera tenella in the annual growth environment during the both periods; Panicum maximum (early rainy season) and Chamaescy hirta (end of the rainy season) in the vegetable garden; Eleusine indica (early rainy season) and Galinsoga parviflora (end of the rainy season) in the perennial crop and Sida rhombifolia (early rainy season) and Neonotonia wigrtii (end of the rainy season) in the pasture. Lower diversity indices and evenness were observed in the pasture environment. Sampling time presented a higher impact on similarities when compared to the different environments.
\end{abstract}

Keywords: Jatropha curcas, corn, pasture, no-tillage

\section{Composição florística de comunidades de plantas daninhas em diferentes agrossistemas}

\section{Resumo}

Comunidades de plantas daninhas em agrossistemas são diversificadas devido às práticas agronômicas adotadas. Neste trabalho realizou-se um levantamento fitossociológico em comunidade de plantas daninhas em diferentes sistemas de cultivo constituídos de cultivo de milho, olericultura, cultivo perene com pinhão-manso e pastagem de Urochloa brizantha, em Rio Verde, GO, no início (outubro de 2011) e no final (março de 2012) da época chuvosa. Após identificação e contagem das espécies calcularam-se os índices fitossociológicos: densidade, frequência, abundância e importância relativa, e os índices de diversidade de Shannon-Wiener e equitabilidade de Pielou e o coeficiente de similaridade de Sorense. Encontrou-se 46 espécies, distribuídas em dezesseis famílias, com destaque para Poaceae. As espécies mais importantes foram Alternanthera tenella no ambiente de cultivo anual em ambas as épocas; Panicum maximum (início da época chuvosa) e Chamaescy hirta (final da época chuvosa) em horta; Eleusine indica (início da época chuvosa) e Galinsoga parviflora (final da época chuvosa) em cultivo perene; e Sida rhombifolia (início da época chuvosa) e Neonotonia wigrtii (final da época chuvosa) em pastagem. Menores índices de diversidade e de equitabilidade foram observados em área de pastagem. Quanto às similaridades entre tratamentos, a época foi mais determinante do que os ambientes, considerando que as semelhanças entre ambientes foram maiores dentro da mesma época amostrada, exceto para a pastagem no final da estação chuvosa.

Palavras-chave: Jatropha curcas, milho, pastagens, plantio direto 


\section{Introduction}

Phytosociological studies can describe and evaluate natural environments and agro-systems based on plant community characteristics. Such studies can also allow comparisons between weed populations in a given time and space (Correa et al., 2011). Especially in weed communities, continuous evaluations of the floristic composition can indicate trends of variation of the importance of one or more populations; such variations may be associated with agricultural practices (Concenço et al., 2015).

Within agroecosystems, weed communities may interfere on growth, development and consequently on the productivity of cultivated plants, if not managed properly (Ciuberkis et al., 2007). In a study over a period of six years, the weed population dynamics in corn crop was affected by tillage systems (no tillage and conventional tillage with ploughing and harrowing) and by herbicide application and mowing (Correa et al., 2011). In this study, a conventional tillage system increased the relative importance of Cyperus rotundus, Cynodon dactylon and Ipomoea grandifolia. In contrast, no-tillage system increased the occurrence of Bidens pilosa.

Similarly, changes in the composition of weed communities were also observed in different agricultural crops, such as sugarcane (Kuva et al., 2007; Soares et al., 2011), pastures (Ferreira et al., 2014), bean (Tavares et al., 2013), cover crops (Lima et al., 2014; Lamego et al., 2015), manioc (Cardoso et al., 2013; Soares et al., 2015), corn (Correa et al., 2011), corn intercropped with legumes (Oliveira et al., 2014) and corn intercropped with forage (Batista et al., 2014; Concenço et al., 2015), millet (Teodoro et al., 2015), lettuce (Ferreira et al., 2013), Jatropha curcas (Concenço et al., 2014) and coffee under organic management (Maciel et al., 2010a; Partelli et al., 2010).

To analyse impacts of management and farming practices on growth dynamics and occupation of weeds, phytosociological indexes are necessary tools (Concenço et al., 2013). The evaluation of such indices for weed communities in agro-systems allows the adoption of weed control measurements, including managing species of great relative importance (Cruz et al., 2009).

The objective of this research was use phytosociological surveys to evaluate the weed community composition in agro/systems of corn crop, perennial crop with Jatropha curcas, vegetable gardens and pastures at the beginning and at the end of the rainy season.

\section{Material and methods}

The floristic survey was conducted in October 2011 and March 2012 at the experimental area of the Goiano Federal Institute of Education, Science and Technology (IF Goiano) located in the municipality of Rio Verde, GO, Brazil (17048'67" S; 5054'18" W; 754m). The climate in this region, according to Köppen, is Aw, defined as humid tropical characterised by two distinct seasons: a dry season from April to October and a humid season, with heavy rainfalls, from November to March. The annual average rainfall is $1,800 \mathrm{~mm}$ and the annual average temperature is $24^{\circ} \mathrm{C}$.

Sampling was carried out in four contiguous areas with different crop systems: corn crop, vegetable garden, perennial crop with Jatropha curcas and pasture with Urochloa brizantha. Under corn cultivation, the soil disturbance was minimal due to the adopted system (no-tillage); liming and fertilization were performed according to the requirements of the crop, after the chemical-physical analysis of the soil. Weed control was performed with specific herbicides, predominantly glyphosate.

The horticulture area was characterized by constant soil disturbance, high fertility and high water availability. Constant crop rotation included lettuce, cabbage, garlic, onions and carrots. Weed control was carried out mechanically and manually.

The perennial crop environment was cultivated during two years with Jatropha curcas. This system experienced no soil disturbance and in the dry season, the crop was irrigated to meet the water requirement. Weed control was carried out manually, by mowing and with the use of glyphosate between lines.

The Urochloa brizantha pasture was characterized by lack of soil disturbance and the 
absence of liming; soil fertility was not maintained through fertilization. Weed control was performed by mowing.

Except for the Jatropha curcas plot, all areas assessed have been used for crops grown for more than 10 years at the time of this study.

Each environment was divided into similar areas of approximately two hectares in which sixteen samples points per crop systems were used. At each sampling spot, a metallic square of $0.25 \mathrm{~m}^{2}(0.5 \times 0.5 \mathrm{~m})$ was randomly placed. identifing and counting weeds. The procedure was performed in two seasons (beginning and end of the rainy season), with the first assessment on October 28, 2011 and the second on March 19, 2012.

After the identification and counting the individuals, the following phytosociological indices were estimated: relative density [RD $=$ (species density $\times 100) / \sum$ densities]; relative frequency $[R F=($ species frequency $\times 100) /$ $\sum$ frequency]; relative abundance $[R A B=$ (species abundance $\times 100$ ) / [abundance]; importance value index $\left[\mathrm{IVI}=\sum(\mathrm{RD} ; \mathrm{RF} ; \mathrm{RAB})\right]$, which is the weighted evaluation of previous contents and the relative importance $[\mathrm{RI}=(\mathrm{IVI} \times 100) / 300]$, which is the percentage representation of the IVI.

The Shannon-Wiener diversity index [ $H=-\sum_{i=1} p_{i} \ln \left(p_{i}\right)$ ] (Pinto Coelho, 2000) was calculated, where pi is the proportion of the sample containing individuals of the population $i$; and the evenness index of Pielou or uniformity [ $J=H / H_{\max }$ ], which is the ratio of the population diversity index and the maximum and theoretical diversity index, obtained when the rated factor shows no variation between populations.

Similarities between environments and samplings were estimated using the Sorensen coefficient. Similarity estimates were interpreted with a dendrogram constructed using the unweighted average (UPGMA). To estimate the adjustment between the dissimilarity matrix and the dendrogram, the cophenetic correlation coefficient ( $r$ ) was calculated.

\section{Results and discussion}

Were identified 13,123 individuals of 46 species and sixteen botanical families. Most individuals $(86.7 \%)$ occurred in the early rainy season, while in the dry season, $13.3 \%$ were sampled. The families Poaceae (11), Asteraceae (9), Amaranthaceae (4), Euphorbiaceae (4) and Fabaceae (4) presented the largest number of species, considering the four environments and the two evaluation periods.

The five species that presented the higher frequencies at the beginning of the rainy season were Nicandra physaloides (20.0\%), Galinsoga parviflora (14.0\%), Commelina benghalensis (14.0\%), Panicum maximum (12.0\%) and Portulaca oleracea (10.0\%), belonging to the families Solanaceae, Asteraceae, Commelinaceae, Poaceae and Portulacaceae, respectively. In the dry season, species with higher frequencies were Digitaria horizontalis (12.7\%), Commelina benghalensis (12.0\%), Eleusine indica (9.1\%), Portulaca oleracea (7.6\%) and Galinsoga parviflora (6.5\%), belonging, respectively, to the families Poaceae, Commelinaceae, Poaceae, Portulacaceae and Asteraceae.

Species of the Poaceae family usually have high phenotypic plasticity, with more competitive characteristics, such as the production of large numbers of seeds, alternative forms of propagation and a high capacity of spread, justifying the occurrence of this family in different environments (Blanco, 2014). Similar results were observed by Tavares et al. (2013) in bean crops at three sowing dates, by Maciel et al. (2010a) in organically cultivated coffee, by Cunha et al. (2014) in pepper cultivation in no and conventional tillage systems and by Maciel et al. (2010b) with lawns.

In table 1 the floristic composition of weeds in the annual corn crop is presented, evaluated at the beginning and end of the rainy season, respectively. The five weed species with the highest RF values in the early rainy season were Commelina benghalensis (13.9\%), Cyperus rotundus (9.6\%), Solanum americanum (9.6\%), Bidens pilosa (8.7\%) and Zea mays (8.7\%), consisting of "volunteer corn plant" from the previous crop. At the end of the rainy season, the species Digitaria horizontalis (12,4\%), Urochloa plantaginea $(12,4 \%), C$. benghalensis $(11,5 \%)$, Alternanthera tenella $(11,5 \%)$ and Nicandra physaloides $(8,0 \%)$ were more frequent. 
Table 1. Frequency (RF), density (RD), abundance (RAB) and relative importance (RI) of weed species in annual corn crop, evaluated at the beginning and the end of the rainy season in Rio Verde - GO, Brazil, 2013.

\begin{tabular}{|c|c|c|c|c|c|c|c|c|}
\hline \multirow{2}{*}{ Species } & \multicolumn{4}{|c|}{ Beginning of the rainy season } & \multicolumn{4}{|c|}{ End of the rainy season } \\
\hline & RF\% & RD\% & RAB\% & $\mathrm{RI} \%$ & RF\% & RD\% & RAB\% & $\mathrm{RI} \%$ \\
\hline Acanthospermum australe & 1.7 & 0.14 & 0.09 & 0.66 & 0.88 & 1.2 & 9.3 & 3.8 \\
\hline Alternanthera tenella & 0.87 & 47.7 & 65.9 & 38.2 & 11.5 & 27.1 & 15.9 & 18.2 \\
\hline Amaranthus hybridus & 1.7 & 0.86 & 0.59 & 1.1 & 4.4 & 0.15 & 0.23 & 1.6 \\
\hline Amaranthus retroflexus & 1.7 & 0.02 & 0.02 & 0.59 & --- & ---- & ---- & --- \\
\hline Amaranthus viridis & --- & ---- & ---- & ---- & 2.6 & 1.1 & 2.7 & 2.1 \\
\hline Argemone mexicana & --- & ---- & --- & ---- & 6.2 & 8.2 & 9.0 & 7.8 \\
\hline Bidens pilosa & 8.7 & 0.29 & 0.04 & 3.0 & 1.8 & 0.61 & 2.3 & 1.6 \\
\hline Cenchrus echinatus & 0.87 & 1.9 & 2.6 & 1.8 & --- & ---- & --- & --- \\
\hline Chamaesyce hirta & ---- & ---- & --- & ---- & 4.4 & 2.1 & 3.2 & 3.3 \\
\hline Commelina benghalensis & 13.9 & 12.3 & 1.1 & 9.1 & 11.5 & 9.1 & 5.4 & 8.7 \\
\hline Conyza bonariensis & 0.87 & 0.05 & 0.06 & 0.33 & --- & ---- & --- & --- \\
\hline Cyperus rotundus & 9.6 & 3.0 & 0.37 & 4.3 & 2.6 & 2.0 & 5.0 & 3.2 \\
\hline Desmodium tortuosum & 3.5 & 0.07 & 0.02 & 1.2 & --- & --- & ---- & ---- \\
\hline Digitaria horizontalis & 0.87 & 5.9 & 8.2 & 5.0 & 12.4 & 8.2 & 4.5 & 8.4 \\
\hline Digitaria insularis & 0.87 & 0.05 & 0.06 & 0.33 & ---- & ---- & ---- & ---- \\
\hline Eleusine indica & 1.7 & 8.1 & 5.6 & 5.2 & 7.1 & 11.4 & 10.9 & 9.8 \\
\hline Galinsoga parviflora & --- & --- & ---- & --- & 0.88 & 0.15 & 1.2 & 0.73 \\
\hline Ipomoea purpurea & 2.6 & 0.41 & 0.19 & 1.1 & 3.5 & 1.2 & 2.3 & 2.4 \\
\hline Nicandra physaloides & 6.1 & 7.4 & 1.5 & 5.0 & 8.0 & 10.4 & 8.8 & 9.0 \\
\hline Panicum maximum & 0.87 & 7.5 & 10.3 & 6.2 & 0.88 & 0.61 & 4.6 & 2.0 \\
\hline Pennisetum americanum & 7.0 & 0.05 & 0.01 & 2.3 & --- & -- & --- & -- \\
\hline Portulaca oleracea & 0.87 & 2.3 & 3.1 & 2.1 & 6.2 & 4.6 & 5.0 & 5.2 \\
\hline Ricinus communis & 7.0 & 0.16 & 0.03 & 2.4 & --- & --- & --- & --- \\
\hline Sida rhombifolia & 5.2 & 0.20 & 0.05 & 1.8 & 2.6 & 1.7 & 4.3 & 2.9 \\
\hline Solanum americanum & 9.6 & 1.5 & 0.19 & 3.8 & ---- & --- & ---- & --- \\
\hline Tridax procumbens & 5.2 & 0.02 & 0.01 & 1.7 & --- & --- & --- & --- \\
\hline Urochloa plantaginea & ---- & ---- & ---- & ---- & 12.4 & 10.1 & 5.5 & 9.3 \\
\hline Zea mays* & 8.7 & 0.05 & 0.01 & 2.9 & ---- & --- & ---- & ---- \\
\hline
\end{tabular}

It should be noticed that in this environment, for both samplings, the species A. tenella showed significantly higher RI values than the other species. At the beginning of the rainy season, $A$. tenella showed a high RD value of $47.7 \%$ with concentrated distribution (RAB $=65.9 \%$ ) (Table 1). Similarly, at the end of the rainy season, this species had higher RD (27.1\%) and RAB (15.9\%) values and, most importantly, a higher RI value (18.2\%). Higher RI values for Eleusine indica (9.8\%), U. plantaginea (9.3\%), N. physaloides (9.0\%), C. benghalensis (8.7\%) and D. horizontalis (8.4\%) were also observed (Table 1). A. tenella showed vigorous growth, which usually explains the large population and abundance of this specie in areas that it infests. Its rapid growth provides shading and therefore positively affects neighbouring plants (Moreira \& Bragança, 2010; Batista et al., 2014). The largest expression represented in the rainy season may be related to greater water availability, favouring further development.

In vegetable gardens, several species showed similar RF values and weeds with the highest values were C. hirta and E. indica, both with 13.2\%; and E. pilosa with $11.3 \%$ for the first evaluation. At the end of the rainy season (second evaluation), the most frequent species were E. indica (16\%), D. horizontalis (14.7\%), C. hirta (13.3\%) and C. benghalensis (13.3\%) (Table 2). Several species showed high numbers of individuals at the beginning of the rainy season, especially E. pilosa (14.5\%), P. maximum (13.6\%), D. horizontalis (12.8\%), C. hirta (12.7\%), A. conyzoides (12.7\%) and G. parviflora (11.7\%). However, the most populous species did not presented higher RAB values (Table 2). Even with a median RAB value (5.3\%), E. pilosa was characterised as a species of high Rl, with $10.4 \%$, only surpassed by P. maximum with $15.0 \%$.

Towards the end of the rainy season, the species with high RD values also presented higher 
values for other parameters; C. hirta and D. horizontalis were the more dense $(27.7$ and $17.7 \%$, respectively) and most abundant (19.0 and $11.0 \%$, respectively) species, with higher RI values (20.0 and $14.5 \%$, respectively). It is noteworthy that in horticultural crops, the predominant species were C. hirta, G. parviflora, D. horizontalis and $E$. indica; these species can germinate and grow faster, have short development cycles and produce high amounts of diaspores, which may favour the re-infestation (Carvalho et al., 2008a; 2008b). In general, in areas cultivated with vegetables, because of the wide availability of resources (water and nutrients) and the high frequency of soil disturbance, perennial species, such as $C$. benghalensis and Cyperus rotundus, are often found (Ferreira et al, 2013; Cunha et al., 2014).

Table 2. Frequency (RF), density (RD), abundance (RAB) and relative importance (RI) of weed species in the vegetable garden, assessed at the beginning and the end of the rainy season, in Rio Verde - GO, Brazil, 2013

\begin{tabular}{|c|c|c|c|c|c|c|c|c|}
\hline \multirow{2}{*}{ Species } & \multicolumn{4}{|c|}{ Beginning of the rainy season } & \multicolumn{4}{|c|}{ End of the rainy season } \\
\hline & RF\% & RD\% & RAB\% & $\mathrm{RI} \%$ & RF\% & RD\% & RAB\% & $\mathrm{RI} \%$ \\
\hline Amaranthus retroflexus & 0.94 & 0.08 & 0.36 & 0.46 & 1.3 & 0.47 & 3.2 & 1.7 \\
\hline Ageratum conyzoides & 6.6 & 12.7 & 7.9 & 9.0 & --- & --- & --- & ---- \\
\hline Amaranthus hybridus & 0.94 & 2.9 & 12.7 & 5.5 & 2.7 & 0.93 & 3.2 & 2.3 \\
\hline Cenchrus echinatus & 0.94 & 0.08 & 0.36 & 0.46 & ---- & --- & ---- & ---- \\
\hline Chamaesyce hirta & 13.2 & 12.7 & 4.0 & 10.0 & 13.3 & 27.7 & 19.0 & 20.0 \\
\hline Commelina benghalensis & 6.6 & 2.0 & 1.2 & 3.3 & 13.3 & 10.9 & 7.5 & 10.6 \\
\hline Conyza bonariensis & 9.4 & 2.4 & 1.0 & 4.3 & 4.0 & 3.5 & 8.0 & 5.2 \\
\hline Cyperus rotundus & 1.9 & 0.50 & 1.09 & 1.2 & 9.3 & 8.4 & 8.2 & 8.6 \\
\hline Digitaria horizontalis & 7.5 & 12.8 & 7.0 & 9.1 & 14.7 & 17.7 & 11.0 & 14.5 \\
\hline Digitaria insularis & 0.94 & 0.08 & 0.36 & 0.46 & 8.0 & 8.4 & 9.6 & 8.6 \\
\hline Duranta repens & 0.94 & 2.1 & 9.1 & 4.0 & ---- & ---- & ---- & ---- \\
\hline Eleusine indica & 13.2 & 6.7 & 2.1 & 7.3 & 16.0 & 10.9 & 6.3 & 11.1 \\
\hline Emilia fosbergii & 3.7 & 1.5 & 1.6 & 2.3 & 1.3 & 0.70 & 4.8 & 2.3 \\
\hline Eragrostis pilosa & 11.3 & 14.5 & 5.3 & 10.4 & ---- & --- & --- & ---- \\
\hline Galinsoga parviflora & 6.6 & 11.7 & 7.3 & 8.5 & 4.0 & 2.1 & 4.8 & 3.6 \\
\hline Gnaphalium coractatum & 0.94 & 0.08 & 0.36 & 0.46 & ---- & ---- & ---- & ---- \\
\hline Panicum maximum & 1.9 & 13.6 & 29.6 & 15.0 & 8.0 & 4.2 & 4.8 & 5.7 \\
\hline Pilea microphylla & 0.94 & 0.25 & 1.09 & 0.76 & ---- & ---- & ---- & ---- \\
\hline Portulaca oleracea & 5.7 & 1.4 & 1.0 & 2.7 & 4.0 & 4.2 & 9.6 & 5.9 \\
\hline Richardia brasiliensis & 3.8 & 0.58 & 0.64 & 1.7 & ---- & ---- & ---- & ---- \\
\hline Sonchus oleraceus & 0.94 & 0.17 & 0.73 & 0.61 & ---- & ---- & ---- & ---- \\
\hline Tridax procumbens & 0.94 & 1.2 & 5.1 & 2.4 & ---- & ---- & ---- & --- \\
\hline
\end{tabular}

In the perennial crop environment with Jatropha curcas cultivation, the species with the highest RF values at the beginning of the rainy season were E. indica (9.5\%), C. benghalensis (9.5\%) and Portulaca oleracea (8.9\%) (Table 3). E. indica also showed high RD (28.8\%) RAB (19.3\%) and RI (19.2\%) values, followed by C. benghalensis and $A$. tenella with RI values of $10.5 \%$. A. tenella was also the most abundant species (RAB 14.3\%) at the beginning of the rainy season.

At the end of the rainy season, $G$. parviflora (17.5\%), U. decumbens (13.7\%) and D. horizontalis (12.5\%) had higher RF values (Table 3). In terms of abundance, an important parameter defining the population size of a particular species in a particular habitat, the highest values was observed for Sida rhombifolia (16.9\%) and G. parviflora (15.7\%). The determination of these species in concentrated areas is of great importance in chemical or mechanical control and allows the use of specific management practices in areas of high infestation. Similar to our study, Monquero \& Silva (2007) found a high importance of grass species in agro-systems of peach and eucalyptus, especially for the species $D$. horizontalis and $U$. decumbens, respectively. In our study, RD values were also high for $G$. parviflora $(30.7 \%)$, characterising it as a species of higher $\mathrm{Rl}$ at the end of the rainy season in this system.

The use of forage crops has received considerable attention because of its competitive and allelopathic effects which alter the composition and suppress the germination of 
many weeds (Bellinder et al., 2004). Table 4 shows the small number of species in this environment. At the beginning of the rainy season, C. incana, S. rhombifolia and N. physaloides had higher RF values compared to the other species, at the beginning of the rainy season, reaching a combined value of $76 \%$. Similarly, at the end of the rainy season, $N$. wightii and $C$. incana reached a combined RF value of $63.1 \%$.

Table 3. Frequency (RF), density (RD), abundance (RAB) and relative importance (RI) of weed species in the perennial crop (Jatropha curcas) environment assessed at the beginning and the end of the rainy season, in Rio Verde - GO, Brazil, 2013

\begin{tabular}{|c|c|c|c|c|c|c|c|c|}
\hline \multirow{2}{*}{ Species } & \multicolumn{4}{|c|}{ Beginning of the rainy season } & \multicolumn{4}{|c|}{ End of the rainy season } \\
\hline & RF\% & RD\% & RAB\% & $\mathrm{RI} \%$ & RF\% & RD\% & RAB\% & $\mathrm{RI} \%$ \\
\hline Alternanthera tenella & 5.3 & 12.0 & 14.3 & 10.5 & $\begin{array}{ll}--- \\
-\end{array}$ & $\begin{array}{ll}--- \\
-\end{array}$ & --- & $\begin{array}{c}--- \\
--\end{array}$ \\
\hline Amaranthus hybridus & ---- & ---- & --- & ---- & 1.2 & 0.17 & 1.20 & 0.87 \\
\hline Amaranthus retroflexus & --- & --- & --- & --- & 1.2 & 0.17 & 1.20 & 0.87 \\
\hline Amaranthus viridis & 5.9 & 6.7 & 7.2 & 6.6 & 8.7 & 5.2 & 5.3 & 6.4 \\
\hline Bidens pilosa & 0.59 & 0.26 & 2.8 & 1.22 & 3.7 & 1.9 & 4.4 & 3.3 \\
\hline Cenchrus echinatus & 2.4 & 0.73 & 2.0 & 1.7 & --- & --- & --- & --- \\
\hline Chamaesyce hirta & 5.9 & 3.1 & 3.4 & 4.1 & 1.2 & 0.34 & 2.4 & 1.3 \\
\hline Commelina benghalensis & 9.5 & 13.1 & 8.8 & 10.5 & 8.7 & 3.7 & 3.8 & 5.4 \\
\hline Conyza bonariensis & 3.5 & 0.82 & 1.5 & 1.9 & ---- & --- & --- & --- \\
\hline Cyperus rotundus & 5.3 & 2.4 & 2.9 & 3.5 & 8.7 & 7.8 & 7.9 & 8.1 \\
\hline Digitaria horizontalis & 7.1 & 11.3 & 10.1 & 9.5 & 12.5 & 16.5 & 11.8 & 13.6 \\
\hline Digitaria insularis & 4.1 & 1.8 & 2.8 & 2.9 & ---- & --- & --- & --- \\
\hline Eleusine indica & 9.5 & 28.8 & 19.3 & 19.2 & 8.7 & 6.8 & 6.9 & 7.5 \\
\hline Emilia fosbergii & 4.7 & 1.0 & 1.3 & 2.4 & 1.2 & 0.68 & 4.8 & 2.2 \\
\hline Euphorbia heterophylla & 1.2 & 0.05 & 0.28 & 0.51 & --- & --- & ---- & --- \\
\hline Galinsoga parviflora & --- & --- & --- & --- & 17.5 & 30.7 & 15.7 & 21.3 \\
\hline Nicandra physaloides & ---- & --- & --- & ---- & 1.2 & 0.17 & 1.2 & 0.87 \\
\hline Pennisetum americanum & 4.7 & 0.31 & 0.42 & 1.8 & --- & --- & --- & --- \\
\hline Phyllanthus tenellus & 1.2 & 0.54 & 2.9 & 1.5 & --- & ---- & --- & --- \\
\hline Portulaca oleracea & 8.9 & 6.8 & 4.9 & 6.7 & 10.0 & 5.2 & 4.7 & 6.6 \\
\hline Ricinus communis & 2.4 & 1.3 & 3.6 & 2.4 & --- & --- & --- & --- \\
\hline Sida cordifolia & 4.7 & 1.2 & 1.6 & 2.5 & ---- & ---- & ---- & ---- \\
\hline Sida rhombifolia & 5.9 & 5.0 & 5.3 & 5.4 & 1.2 & 2.4 & 16.9 & 6.8 \\
\hline Urochloa brizantha & 4.7 & 2.4 & 3.3 & 3.5 & ---- & ---- & ---- & --- \\
\hline Urochloa decumbens & 1.2 & 0.10 & 0.56 & 0.62 & 13.7 & 18.2 & 11.8 & 14.6 \\
\hline Urochloa plantaginea & 0.59 & 0.03 & 0.38 & 0.33 & ---- & ---- & ---- & ---- \\
\hline Zea mays & 0.59 & 0.03 & 0.38 & 0.33 & ---- & --- & --- & --- \\
\hline
\end{tabular}

Table 4. Frequency (RF), density (RD), abundance (RAB) and relative importance (RI) of weed species in pasture Urochloa brizantha assessed at the beginning and the end of the rainy season, in Rio Verde - GO, Brazil, 2013

\begin{tabular}{|c|c|c|c|c|c|c|c|c|}
\hline \multirow{2}{*}{ Species } & \multicolumn{4}{|c|}{ Beginning of the rainy season } & \multicolumn{4}{|c|}{ End of the rainy season } \\
\hline & RF\% & RD\% & RAB\% & $\mathrm{RI} \%$ & RF\% & RD\% & RAB\% & $\mathrm{RI} \%$ \\
\hline Alternanthera tenella & 8.0 & 5.0 & 9.8 & 7.6 & 15.8 & 11.7 & 15.7 & 14.4 \\
\hline Amaranthus viridis & 4.0 & 5.0 & 19.6 & 9.5 & ---- & ---- & ---- & ---- \\
\hline Commelina benghalensis & 4.0 & 1.7 & 6.5 & 4.1 & 5.3 & 3.3 & 13.5 & 7.4 \\
\hline Crotalaria incana & 24.0 & 35.0 & 22.8 & 27.3 & 21.0 & 30.0 & 30.3 & 27.1 \\
\hline Neonotonia wightii & ---- & ---- & ---- & ---- & 42.1 & 40.0 & 20.2 & 34.1 \\
\hline Nicandra physaloides & 16.0 & 10.0 & 9.8 & 11.9 & ---- & ---- & ---- & ---- \\
\hline Phyllanthus tenellus & 1.74 & 0.11 & 0.08 & 0.64 & ---- & ---- & ---- & ---- \\
\hline Sida rhombifolia & 36.0 & 35.0 & 15.2 & 28.7 & 15.8 & 15.0 & 20.2 & 17.0 \\
\hline
\end{tabular}

In pastures located in the state of Mato Grosso do Sul, Guglieri-Caporal et al. (2010) observed that species of the Fabaceae family are among the most frequent ones, similarly to $C$. incana in this survey. In our study, the species $C$. incana and N. wightii, which stood out in terms of RF values, also had the highest RD values (35\%) and RI values (28.7 and $27.3 \%$, respectively). In terms of RAB values, the three species with the highest values at the beginning of the rainy 
season were C. incana (22.8\%) A. viridis (19.6\%) and S. rhombifolia (15.2\%). At the end of the rainy season, the species $N$. wightii and $C$. incana had higher RD, RAB and RI values in pasture dominated by U. brizantha (Table 4).

Although management practices influence the composition of weed communities, it was possible to observe that weed species of the Poaceae family was presented in various conditions, except in pastures. The seeds of species of Poaceae generally have short longevity, and in the pastures are subject to germination followed by death, due to the difficulty to overcome the dense straw layer and also by grazing by animals (Pitelli, 1998).

The lowest number of weed species in systems involving pastures in relation to other environments and the less density of individuals due to the presence of $U$. brizantha already established as forage. In studies on the soil seed bank of weeds in continuous farming systems, exclusive pastures and pastures integrated with crops, Ikeda et al. (2007) observed that cultivation systems containing perennial forage grasses (P. maximum, U. brizantha, $U$. decumbens and Andropogon gayanus) had lower weed seed densities and fewer weed species in the soil seed bank, compared to agro-systems cultivated with crops.

Considering RI values across different environments, it becomes evident that management procedures such as crop

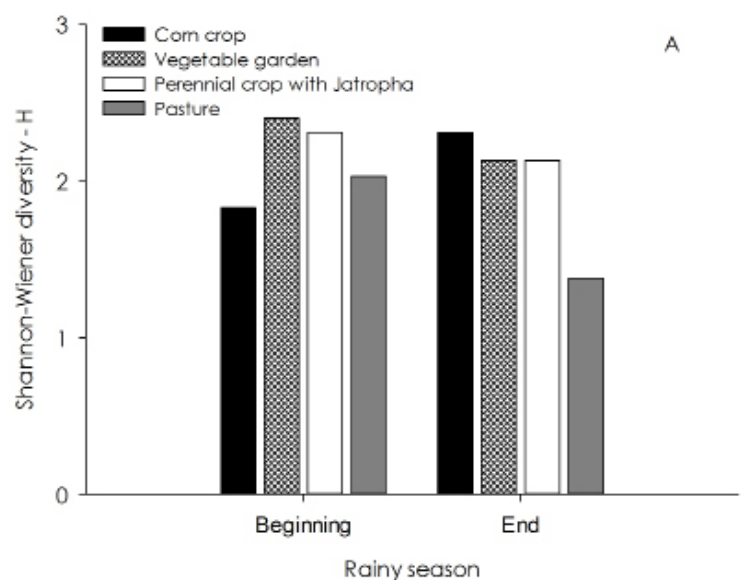

rotation, no-tillage or reduced soil disturbance, intercropping with legumes and integration of crop-livestock allow to adapt or complement integrated weed management in different agrosystems. Several studies have shown the effects of management on reducing the persistence of weeds in agro-systems (Fernandes et al., 1999; Jakelaitis et al., 2003; Meschede et al., 2007; Ikeda et al 2007; Sodre Filho et al., 2008).

The Shannon-Wiener diversity is considered high when it is above 3, average between 2 and 3, low between 1 and 2 and very low less than 1 (Cavalcanti \& Larrazábal, 2004). Regarding the weed diversity of the environments in the two seasons evaluated, we noted that the average species diversity at the beginning of the rainy season (2.0) was close to the average diversity found in the dry season (1.9) (Figure 1A). Diversity estimates were considered on the average for annual crop corn evaluated at the end of the rainy season and for perennial crop of the Jatropha curcas and vegetables garden, for both evaluated periods. The most diverse environment at the beginning of the rainy season was the horticultural crop (2.4), while at the end of the rainy season, it was the annual corn crop (2.3) (Figure 1A). Weed diversity was low for pasture, both at the beginning (1.5) and at the end (1.4) of the rainy season, and for the annual corn crop at the beginning of the rainy season (1.8) (Figure 1A).

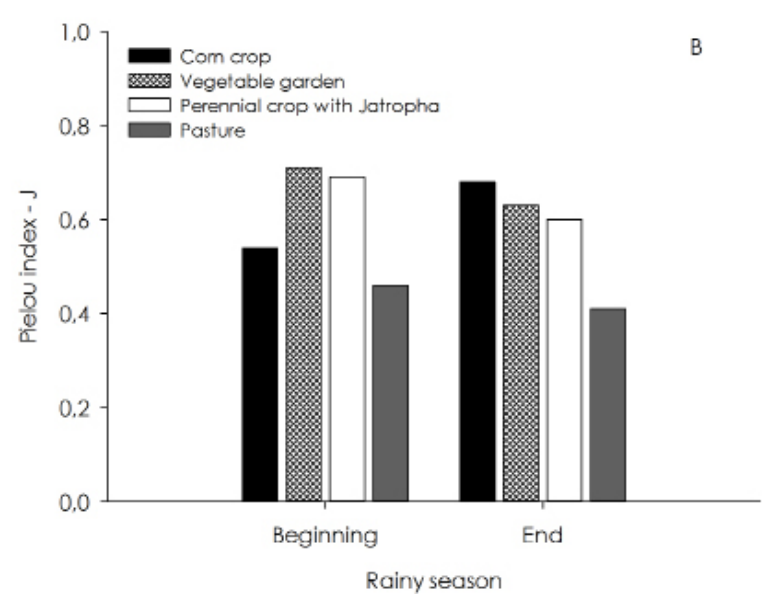

Figure 1. Shannon-Wiener index - H (A) and Pielou index - J (B) for different environments determined at the beginning and the end of the rainy season, Rio Verde - GO, Brazil, 2013.

Equitability varied between 0 and 1 and is considered high if the values are above 0.5. According to Cavalcanti \& Larrazábal,
(2004), low values demonstrate a dominance of one or more species in the studied community, while high equitability means uniform distribution 
between species in the sample and that, despite the complexity of the community, individuals are well distributed. Our Shannon-Wiener index values are consistent with those found for the evenness Pielou index, where at the beginning of the rainy season, average evenness (0.60) was close to the average evenness at the end of the rainy season (0.58). Between environments, at the beginning of the rainy season, the largest estimate of equitability was found in the vegetable crop environment (0.71), while at the end of the rainy season, the largest equitability value was observed for the annual cultivation environment (0.68). Only pasture had a poor uniform composition for both evaluated periods (Figure 1B).

Figure 2 shows the similarity between the evaluated environments, considering the two periods. The most similar environments are the corn crop with the perennial crop with Jatropha curcas at the end of the rainy season (0.73), both of which showed a similarity of 0.65 with the horticultural crop. These three environments were similar at 0.55 to the annual corn crop at the start of the rainy season, and the similarity of these environments with the horticultural crop environment was 0.29 .

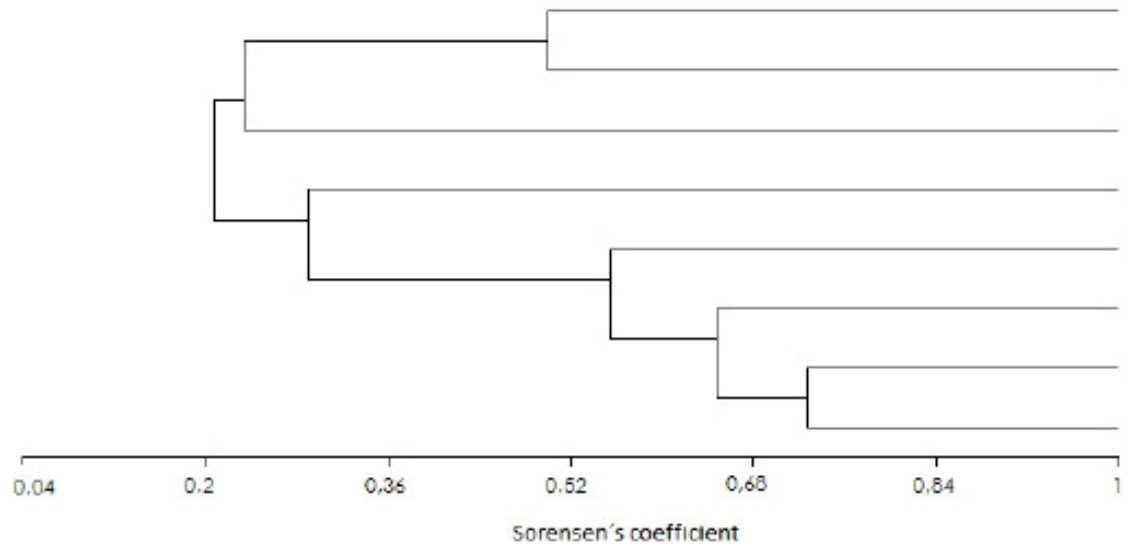

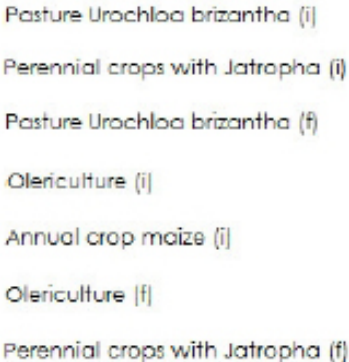

Annual crop maize (f)

Figure 2. Similarity dendrogram of four environments determined at the beginning (i) and the end ( $\mathrm{f}$ ) of the rainy season in Rio Verde - GO, Brazil, 2013.

Sorensen's coefficient value of the pasture at the beginning of the rainy season was similar to the value of the perennial cultivation environment with Jatropha curcas (0.50) and both showed similarity with the pasture area found at the end of the rainy season (0.23). The first and second group had a similarity of 0.21 . The similarity coefficients showed high variability, indicating a condition for the establishment of groups of the environments with a certain level of similarity, regarding the specific composition.

The cophenetic correlation coefficient (r) was 0.87, indicating an adequate adjustment between the dissimilarity matrix and the resulting matrix provided by the grouping method. However, Kuva et al. (2007) pointed out that the similarity index considers only the absence or presence of the species, failing to consider information on density, biomass and distribution pattern of the species.

Even when dealing with neighbouring areas under the same climatic conditions, evaluation of the floristic composition showed significant patterns of variation for the phytosociological indices, diversity, equitability and similarity between different environments. These differences are related to the crop, soil management and weed control method, which are crucial for weed community composition.

\section{Conclusions}

In the present study, the most important weed species were A. tenella in the corn crop; $P$. maximum and $C$. hirta in the horticultural crop; $E$. indica and G. parviflora in the Jatropha curcas crop and S. rhombifolia and N. wigrtii in pastures at the beginning and end of the rainy season, respectively.

Environments with corn, Jatropha curcas and horticultural crops showed higher evenness and similarity.

The pasture environment had a low 
diversity and uneven distribution of individuals among species. Similarly, the environment represented by the corn crop presented lower diversity at the beginning of the rainy season.

\section{References}

Batista, K., Giacomini, A.A., Gerdes, L., Mattos, W.T. de, Andrade, J.B. de. 2014. Phytosociological survey of weeds in areas of crop-livestock integration. American Journal of Plant Sciences 5: 1090-1097.

Bellinder, R.R., Dillard, H.R., Shah, D.A. 2004. Weed seed bank community responses to crop rotation. Crop Protection 23: 95-101.

Blanco, F.M.G. 2014. Classificação e mecanismos de sobrevivência das plantas daninhas. In: Monquero, P.A. (ed). Aspectos da biologia e manejo das plantas daninhas. Rima, São Carlos, Brasil, p. 33-60.

Cardoso, A.D., Viana, A.E.S., Barbosa, R.P. Teixeira, P.R.G., Cardoso Júnior, N.S.., Fogaça, J.J.N.L. 2013. Levantamento fitossociológico de plantas daninhas na cultura da mandioca em Vitória da Conquista, Bahia. Bioscience Journal 29: $1130-1140$.

Carvalho, L.B. de, Pitelli, R.A., Cecílio Filho, A.B., Bianco, S., Guzzo, C.D. 2008a. Interferência e estudo fitossociológico da comunidade infestante em beterraba de semeadura direta. Planta Daninha 26: 291-299.

Carvalho, L.B. de, Pitelli, R.A, Cecílio Filho, A.B., Bianco, S., Guzzo, C.D. 2008b. Interferência e estudo fitossociológico da comunidade infestante na cultura da beterraba transplantada. Acta Scientiarum Agronomy 30: 325-331.

Cavalcanti, E.A.H., Larrazábal, M.E.L. 2004. Macrozooplâncton da Zona Econômica Exclusiva do Nordeste do Brasil (segunda expedição oceanográfica - REVIZEE/NE II) com ênfase em Copepoda (Crustacea). Revista Brasileira de Zoologia 21: 467-475.

Ciuberkis, S.; Bernotas, S.; Raudonius, S.; Felix, J. 2007. Effect of weed emergence time and intervals of weed and crop competition on potato yield. Weed Technology 21: 213-218.

Concenço, G., Tomazi, M., Correia, I.V.T., Santos, S.A., Galon, L. 2013. Phytosociological surveys: tools for weed science? Planta Daninha 31: 469482.

Concenço, G., Silva, C.J., Correia, I.V.T., Silva, J.A.N., Santos, S.A., Fróes, A.L., Fábris, D.N., Staut, L.A. 2014. Occurrence of weed species in Jatropha curcas intercropping systems. Planta Daninha 32: 327-334.
Concenço, G., Marques, R.F., Santos, S.A., Correia, I.V.T., Palharini, W.G., Alves, M.S., Melo, T.S., Xavier, L.B., Linhares, L.G. 2015. Integration crop-livestock: is it efficient in suppressing troublesome weeds? A case study. African Journal of Agricultural Research 10: 1882-1890.

Corrêa, M. L. P., Galvão, J.C.C., Fontanetti, A., Ferreira, L.R., Miranda, G.V. 2011. Dinâmica populacional de plantas daninhas na cultura do milho em função de adubação e manejo. Revista Ciência Agronômica 42: 354-363.

Cruz. D.L.S., Rodrigues, G.S., Dias, F.O., Alves, J.M.A.; Albuquerque, J.A.A. 2009. Levantamento de plantas daninhas em área rotacionada com as culturas de soja, milho e arroz irrigado no Cerrado de Roraima. Revista Agroambiente 3: 58-63.

Cunha, J.L.X.L., Freitas, F.C.L., Coelho, M.E.H., Silva, M.G.O., Silva, K.S., Nascimento, P.G.M.L. 2014. Fitossociologia de plantas daninhas na cultura do pimentão nos sistemas de plantio direto e convencional. Revista Agroambiente 8: 119-126.

Fernandes, M.F.; Barreto, A.C.; Emídio Filho, J. 1999. Fitomassa de adubos verdes e controle de plantas daninhas em diferentes densidades populacionais de leguminosas. Pesquisa Agropecuária Brasileira 34: 1593-1600.

Ferreira, I.C.P.V., Araujo, A.V.de, Nascimento, A.L., Cavalcanti, T.F.M., Tuffi Santos, L.D. 2013. Cobertura morta e adubação orgânica na produção de alface e supressão de plantas daninhas. Revista Ceres 60: 582-588.

Ferreira, E.A., Fernandez, A.G., Souza, C.P. de, Felipe, M.A., Santos, J.B. dos, Silva, D.V., Guimarães, F.A.R. 2014. Levantamento fitossociológico de plantas daninhas em pastagens degradadas do Médio Vale do Rio Doce, Minas Gerais. Revista Ceres 61: 502-510.

Guglieri-Caporal, A., Caporal, F.J.M., Pott, A. 2010. Phytosociology of sown pasture weeds under two levels of degradation in Brazilian savanna areas, Mato Grosso do Sul State, Brazil. Pesquisa Agropecuária Tropical 40: 312-321.

Ikeda, F.S., Mitja, D., Vilela, L., Carmona, R. 2007. Banco de sementes no solo em sistemas de cultivo lavoura-pastagem. Pesquisa Agropecuária Brasileira 42: 1545-1551.

Kuva, M.A., Pitelli, R.A., Salgado, T.P., Alves, P.L.C.A. 2007. Fitossociologia de comunidades de plantas daninhas em agroecossistema canacrua. Planta Daninha 25: 501-511.

Jakelaitis, A.; Ferreira, L.R.; Silva, A.A.; Agnes, E.L.; Miranda, G.V.; Machado, A.F.L. 2003. Efeitos de sistemas de manejo sobre a população de 
tiririca. Planta Daninha 21: 89-95.

Lamego, F.P., Caratti, F.C., Reinehr, M., Gallon, M., Santi, A.L., Basso, C.J. 2015. Potencial de supressão de plantas daninhas por plantas de cobertura de verão. Comunicata Scientiae 6: 97-105.

Lima, S.F., Timossi, P.C., Almeida, D.P., Silva, U.R. 2014. Fitossociologia de plantas daninhas em convivência com plantas de cobertura. Revista Caatinga 27: 37-47.

Maciel, C.D.G., Poletine, J.P., Oliveira Neto, A.M., Guerra, N., Justiniano, W. 2010a. Levantamento fitossociológico de plantas daninhas em cafezal orgânico. Bragantia 69: 631-636.

Maciel, C.D.G., Hama, J.T., Souza, J.I. de. Levantamento fitossociológico da comunidade infestante em gramado semeado com Paspalum notatum Flügge. 2010b. Pesquisa Agropecuária Tropical 40: 116-118.

Meschede, D.K.; Ferreira, A.B.; Ribeiro Junior, C.C. 2007. Avaliação de diferentes coberturas na supressão de plantas daninhas no cerrado. Planta Daninha 25: 465-471.

Monquero, P.A, Silva, A.C. 2007. Levantamento fitossociológico e banco de sementes das comunidades infestantes em áreas com culturas perenes. Acta Scientiarum Agronomy 29: 315321.

Moreira, H.J.C., Bragança, H.B.N. 2010. Manual de identificação de plantas infestantes. São Paulo: FMC Agricultural Products, $854 \mathrm{p}$.

Oliveira, A.C.S., Coelho, F.C., Crevelari, J.A., Silva, I.F., Rubim, R.F. 2014. Fitossociologia de plantas daninhas em monocultivo de milho e em consórcio com diferentes Fabaceae. Revista Ceres 61: 643-651.

Partelli, F.L., Vieira, H.D., Freitas, S.P., Espindola, J.A.A. 2010. Aspectos fitossociológicos e manejo de plantas espontâneas utilizando espécies de cobertura em cafeeiro Conilon orgânico. Semina: Ciências Agrárias 31: 605-618.

Pinto Coelho, R.M. 2000. Fundamentos em ecologia. Porto Alegre-RS. 252 p.

PITELLI, R.A. 1998. Plantas daninhas no sistema plantio direto de culturas anuais. Revista Plantio Direto 47: 13-18.

Soares, M.B.B., Finotto, E.L., Bolonhezi, D., Carrega, W.C., Albuquerque, J.A.A. de, Pirotta, M.Z. 2011. Fitossociologia de plantas daninhas sob diferentes sistemas de manejo de solo em áreas de reforma de cana crua. Revista Agroambiente 5: 173-181.
Soares, M.R.S., José, A.R.S., Araújo neto, A.C., Lima, R.S., Moreira, E.S., Prado, T.R. 2015. Phytosociological survey of weed in cassava cultivation in Southwestern Bahia, Brazil. African Journal of Agricultural Research 10: 2120-2129.

Sodré Filho, J.; Carmona, R.; Cardoso, A.N; Carvalho, A.M. 2008. Culturas de sucessão ao milho na dinâmica populacional de plantas daninhas. Scientia Agraria, 9: 7-14.

Tavares, C.J., Jakelaitis, A., Rezende, B.P.M., Cunha, P.C.R. 2013. Fitossociologia de plantas daninhas na cultura do feijão. Revista Brasileira de Ciências Agrárias 8: 27-32.

Teodoro, P.E., Ribeiro, L.P., Corrêa, C.C.G., Luz Júnior, R.A.A.da, Souza, M.C.de, Simões, M.S., Torres, F.E. 2015. Phytosociology of weeds in millet under different soil managements in savanna sulmato-grossense. Bioscience Journal 31: 988-996. 